\title{
Performance and Organ Characteristics of Cirina Forda (Westwood) (Lepidoptera: Saturniidae) Larva Meal in Broiler Birds
}

\author{
O.O. Oyegoke ${ }^{1},{ }^{*}$ A. J. Akintola ${ }^{1}$, S.A. Babarinde ${ }^{2}$, Bello, O.I, \\ and Ayandiran, T.A ${ }^{1}$ \\ 1. Department of Pure and Applied Biology, ${ }^{2}$. Department of Crop and Environmental \\ Protection, Ladoke Akintola University of Technology, Ogbomoso, Nigeria
}

\begin{abstract}
A 56-day feeding trial involving 72, day-old Anak broilers was carried out in a completely randomized design to evaluate the performance and organ characteristic of broilers fed Cirina forda larva meals at dietary levels 100,50 and $0 \%$ and tagged Feeds $A, B$ and $C$ respectively. The feeds were compounded as Feed A, 100\% C. forda and $0 \%$ fishmeal; Feed B, 50\% C. forda and 50\% fishmeal and lastly, Feed C, 0\% C. forda and $100 \%$ fishmeal. At the starter and finisher stages of the birds, daily feed intake, mean weight gain, and final body weight were significantly different $(P<0.05)$ among the birds with those fed with Feeds $A$ and $B$ recording higher values than Feed $C$. In the entire carcass parameters measured, significant difference $(p<0.05)$ was established. The dressing weight percentage and live-weights of birds showed significant difference ( $p<0.05) ;$ birds fed with Feeds $A$ and $B$ recorded higher values than those fed Feed $C$. The relative weights of seven visceral organs of broilers fed with Feed $C$ were in all cases significantly higher $(P<0.05)$ than the birds fed with Feeds $A$ and B. The relative weights of the visceral organs decrease with increase content of C. forda larva. This investigation has revealed that, feeds compounded from C. forda larva could be used not only to compound feed for broiler birds, it can facilitate higher growth values at lower inclusion levels like conventional feeds.
\end{abstract}

Keywords: Cirina forda meal, conventional meal, performance, and organ characteristics .

\section{Introduction}

Despite the increase in the global supply of protein, the distribution of the increase has not been equal. The poor state of economy in many developing countries has not made this picture brighter as consumption of high protein foods continues to be out of reach of more than $65-70 \%$ of the people (Nworgu, 2004). Poultry as agricultural enterprises has been suggested as one of the better placed production systems possessing the potential to redress this unenviable status (Leng, 2002) In Nigeria, poultry meat and eggs have been suggested as possessing great potentials for bridging the protein gap noted above in view of the high yielding exotic poultry are easily adaptable to our environment and the technology of production is relatively simple with returns on investment appreciably high (Idufueko, 1984; Madubuike, 1992). However, the poultry industry in Nigeria is facing hard times with more than $50 \%$ of the country's poultry farms closed down and another $30 \%$ forced to reduce their production capacity due to shortage of feed (Esonu et al, 2001). The cost price of some of the existing feed concentrates like groundnut cake, fish meal and soyabean meal has risen astronomically to the extent that it is becoming uneconomical to use them in poultry feeds (Opara, 1996; Esonu et al., 2001). Udedibie (1997) reported that there is constant quest for improving current popular protein sources and finding ways of exploiting the neglected and underutilized ones.

In the tropics, insects form a highly conspicuous invertebrate fauna group and retain large proportion of the wild fauna biomass (Meyer-Rochow, 1975; Dufor, 1987). Insects, especially saturnidae larvae are all over the world known for their dietary acceptability (Golding, 1929; Gardener, 1957; Ene, 1963 and kodondi et al., 1987). The saturniid larvae of Cirina forda (Westwood) has a wide acceptability as a food source, and also serve as an important item of commerce in such Nigeria states like Oyo, Kwara, Kogi, Niger and Kaduna where it has become the most important and marketable insect (Ande, 1991; Fasoranti and Ajiboye, 1993). The larva of the insect has been demonstrated to be acceptable and shown to elicit comparable growth patterns to conventional feeds in Clarias gariepinus (Geoffrey) (Akintola and Oyegoke, 2002). The dietary potentials of this edible larvae in compounding feeds for broiler birds, was also demonstrated by Oyegoke et al., (2006). In view of the huge nutritional potentials that have been demonstrated for the meals compounded from the larva in broiler birds, there is the need to investigate its effects on growth performance, carcass and organ characteristics also. 


\section{Materials And Methods}

This experiment was carried out at Poultry Unit of Faculty of Agricultural Sciences, Ladoke Akintola niversity of technology, Ogbomoso $\left(8^{0} 8^{\prime} \mathrm{N}-8^{0} 14^{\prime} \mathrm{N}\right.$ and $\left.4^{0} 17^{\prime} \mathrm{E}\right)$, Oyo State, Nigeria.

Dried larva form of Cirina forda were purchased from local markets in Ilorin, Kwara State, Nigeria. The larva were oven-dried at $42^{0} \mathrm{C}$ for 7 days to eliminate microorganisms and latter milled to powdery form using a blender. A sample of the dried larva of $\mathrm{C}$. forda was taken and subjected to proximate analysis according to AOAC (1995). Other feed ingredients were purchased from Navada Feeds located in Ogbomoso, Oyo State, Nigeria. These ingredients were added to compound standard diets for the starter and finisher stages of the birds. All diets were compounded to provide 20-23\% Crude protein for the starter phase and 17-19.5\% Crude protein for the finisher phase (Pfizer Nutrient Master Plan, 1992). Similarly, each of the feeds was calculated to contain energy levels of 2,600 kcal and 2,800 kcal for the starter and finisher phases respectively (Moreson Feed Formulation Guide, 1998).

Seventy two day-old Anak broiler chicks were bought from Ajanla farms in Ibadan, Oyo State, Nigeria and were used for this study. The chicks were separated into three dietary treatments namely A,B and C which contained 24 birds per group. Each treatment group was further replicated 3 times with 8 chicks per replicate. Based on the result of the chemical analysis three broiler and finisher broiler diets were formulated and named as Feed A, Feed B and Feed C respectively. Feed A contained 100\% C. forda larva and 0\% Fish meal; Feed B contained 50\% C. forda and 50\% Fish meal; lastly, Feed C contained $0 \%$ C. forda and $100 \%$ Fish meal. All feeds were isoenergetic and isonitrogenous (Tables 1 and 2). Both stages of the birds were reared on a deeplitter system. Feeds and water were supplied ad libitum to the birds and routine vaccination and veterinary treatments were provided throughout the 56 days that the experiment lasted.

Daily feed intake was taken and the weekly weighing of the birds was done every Saturday using (Lark ${ }^{\mathrm{R}}$ MB 2610) balance.

Carcass evaluation of the experimental birds was done at the point of terminating the feeding trial. Four birds per dietary group were fasted for 18 hours, weighed, slaughtered by cutting at the neck region with a sharp knife and thereafter held down for good blood drainages. Slaughtered birds were first weighed before dressing and evisceration. Carcass cuts, offal and organ weight determinations were taken.

Data collected were subjected to analysis of variance and where significant difference $(\mathrm{p}<0.05)$ were observed, the means were separated by least significant difference method ( Steel and Torrie, 1989).

Table 1: Gross composition of diets for the starter phase (0-4 weeks)

\begin{tabular}{llll} 
Ingredients g/100g & Feed A & Feed B & Feed C \\
& $100 \%$ C. forda : & $50 \%$ C. forda : & $0 \%$ C. forda : \\
& $0 \%$ Fishmeal & $50 \%$ Fishmeal & $100 \%$ Fishmeal \\
\hline Bone meal & 2 & 2 & 2 \\
Maize & 45 & 45 & 45 \\
Palm kernel cake & 20 & 20 & 20 \\
Soyabean & 2 & 2 & 2 \\
Groundnut cake & 18 & 18 & 18 \\
Oyster shell & 1 & 1 & 1 \\
Maize bran & 7 & 7 & 7 \\
Lysine & 0.25 & 0.25 & 0.25 \\
Methionine & 0.25 & 0.25 & 0.25 \\
Salt & 0.25 & 0.25 & 0.25 \\
Premix & 0.25 & 0.25 & 0.25 \\
Fishmeal & - & 2 & 9 \\
C. forda larva & 9 & 2 & - \\
Total & 100 & 100 & 100 \\
Calculated composition $(D M)$ & & & \\
Crude protein & 22.96 & 22.87 & 22.74 \\
Crude fat & 3.62 & 3.57 & 3.59 \\
Crude fibre & 3.61 & 3.63 & 3.65 \\
Gross energy (Kcal/kg) & 3,108 & 3,095 & 3,096 \\
& & &
\end{tabular}

${ }^{+}$Provided the following per kg of feed: Vit A,10,000 iu,Vit D3, 2,000 iu; Vit E, 5 iu;Vit K,2 mg; Riboflavin, $4.20 \mathrm{mg}$; Vit B 12, $0.01 \mathrm{mg}$; Pantothenic acid, $5 \mathrm{mg}$; Nicotinic acid, $20 \mathrm{mg}$; Folic acid, $0.5 \mathrm{mg}$; Choline, $3 \mathrm{mg}$; $\mathrm{Mg}$, 56mg; Fe, 20mg; Cu, $10 \mathrm{mg}$; Zn, 50mg; Co, $125 \mathrm{mg}$; Iodine, $0.8 \mathrm{mg}$. 
Table 2: Gross composition of diets for the finisher ( 5-8 weeks )

\begin{tabular}{llll} 
Ingredients $\mathbf{g} / \mathbf{1 0 0 g}$ & Feed A & Feed B & Feed C \\
& $100 \%$ C. forda : & $50 \%$ C. forda : & $0 \%$ C. forda : \\
& $0 \%$ Fishmeal & $50 \%$ Fishmeal & $100 \%$ Fishmeal \\
\hline Bone meal & 2 & 2 & 2 \\
Maize & 47 & 47 & 47 \\
Palm kernel cake & 20 & 20 & 20 \\
Soyabean & 1 & 1 & 2 \\
Groundnut cake & 10 & 10 & 10 \\
Oyster shell & 2 & 2 & 11.85 \\
Maize bran & 11.85 & 11.85 & 1 \\
Lysine & 1 & 1 & 0.45 \\
Methionine & 0.45 & 0.45 & 0.35 \\
Salt & 0.35 & 0.35 & 0.35 \\
Premix & + & 0.35 & - \\
Fishmeal & 0.35 & 2 & - \\
C. forda larva & - & 2 & 100 \\
Total & 9 & 100 & 19.86 \\
Calculated composition $(\mathbf{D M})$ & 100 & & 3.73 \\
Crude protein & 19.74 & 19.97 & 3.76 \\
Crude fat & 3.69 & 3.65 & 3,178 \\
Crude fibre & 3.78 & 3.74 & \\
Gross energy (Kcal/kg) & 3,172 & 3,175 & \\
& & &
\end{tabular}

${ }^{+}$Provided the following per kg of feed: Vit A,10,000 iu,Vit D3, 2,000 iu; Vit E, 5 iu;Vit K,2 mg; Riboflavin, $4.20 \mathrm{mg}$; Vit B 12, $0.01 \mathrm{mg}$; Pantothenic acid, $5 \mathrm{mg}$; Nicotinic acid, $20 \mathrm{mg}$; Folic acid, $0.5 \mathrm{mg}$; Choline, $3 \mathrm{mg}$; $\mathrm{Mg}$, 56mg; Fe, 20mg; Cu, $10 \mathrm{mg}$; Zn, 50mg; Co, $125 \mathrm{mg}$; Iodine, $0.8 \mathrm{mg}$.

Table 3. Proximate analysis of fishmeal and Cirina forda larva

$\begin{array}{lcc}\text { Parameter } & \text { Fishmeal } & \text { Cirina fo } \\ \text { \% Crude protein } & 62.76 & 29.64 \\ \text { \% Crude fat } & 7.59 & 4.18 \\ \text { \% Crude fibre } & 1.05 & 1.63 \\ \text { \% Crude ash } & 16.57 & 3.75 \\ \text { \% Dry matter } & 88.94 & 90.38 \\ \text { Gross energy (kcal/g) } & 3.176 & 2.834\end{array}$

Table 4: Performance characteristics of broiler chicks (starter phase)

\begin{tabular}{|c|c|c|c|c|}
\hline Parameter & $\begin{array}{l}\text { Feed A } \\
100 \% \text { C. forda : } \\
\text { 0\% Fishmeal }\end{array}$ & $\begin{array}{l}\text { Feed B } \\
\mathbf{5 0 \%} \text { C. forda : } \mathbf{5 0 \%} \\
\text { Fishmeal }\end{array}$ & $\begin{array}{l}\text { Feed C } \\
0 \% \text { C. forda }: 100 \% \\
\text { Fishmeal }\end{array}$ & SEM \\
\hline $\begin{array}{l}\text { Daily feed intake }(\mathrm{kg}) \\
\text { Initial body } \\
\text { weight }(\mathrm{kg})\end{array}$ & $\begin{array}{l}0.1442^{b} \\
0.0107^{b}\end{array}$ & $0.0111^{\mathrm{a}}$ & $\begin{array}{l}0.1393^{\mathrm{c}} \\
0.0084^{\mathrm{c}}\end{array}$ & 0.00 \\
\hline & & & & 0.00 \\
\hline $\begin{array}{l}\text { Mean weight gain } \\
(\mathrm{kg})\end{array}$ & $0.1625^{\mathrm{a}}$ & $0.1575^{\mathrm{b}}$ & $0.1175^{\mathrm{c}}$ & 0.01 \\
\hline
\end{tabular}

*means with the different superscript in the same row are significantly different from one another $(\mathrm{p}<0.05)$.

Table 5: Performance characteristics of broiler chicks (finisher phase)

\begin{tabular}{|c|c|c|c|c|}
\hline Parameter & $\begin{array}{l}\text { Feed A } \\
\text { 100\% C. forda : } \\
\text { 0\% Fishmeal }\end{array}$ & $\begin{array}{l}\text { Feed B } \\
\mathbf{5 0 \%} \text { C. forda : } \mathbf{5 0 \%} \\
\text { Fishmeal }\end{array}$ & $\begin{array}{l}\text { Feed C } \\
\text { 0\% C. forda : } 100 \% \\
\text { Fishmeal }\end{array}$ & SEM \\
\hline Daily feed intake (kg) & $0.7385^{\mathrm{b}}$ & $0.7392^{\mathrm{a}}$ & $0.724^{\mathrm{c}}$ & 0.00 \\
\hline Mean weight gain $(\mathrm{kg})$ & $1.6225^{\mathrm{a}}$ & $1.5675^{\mathrm{b}}$ & $1.3025^{\mathrm{c}}$ & 0.05 \\
\hline Final body weight $(\mathrm{kg})$ & $2.29^{\mathrm{a}}$ & $2.29^{\mathrm{a}}$ & $1.62^{\mathrm{b}}$ & 0.11 \\
\hline
\end{tabular}

*means with the different superscript in the same row are significantly different from one another $(\mathrm{p}<0.05)$. 


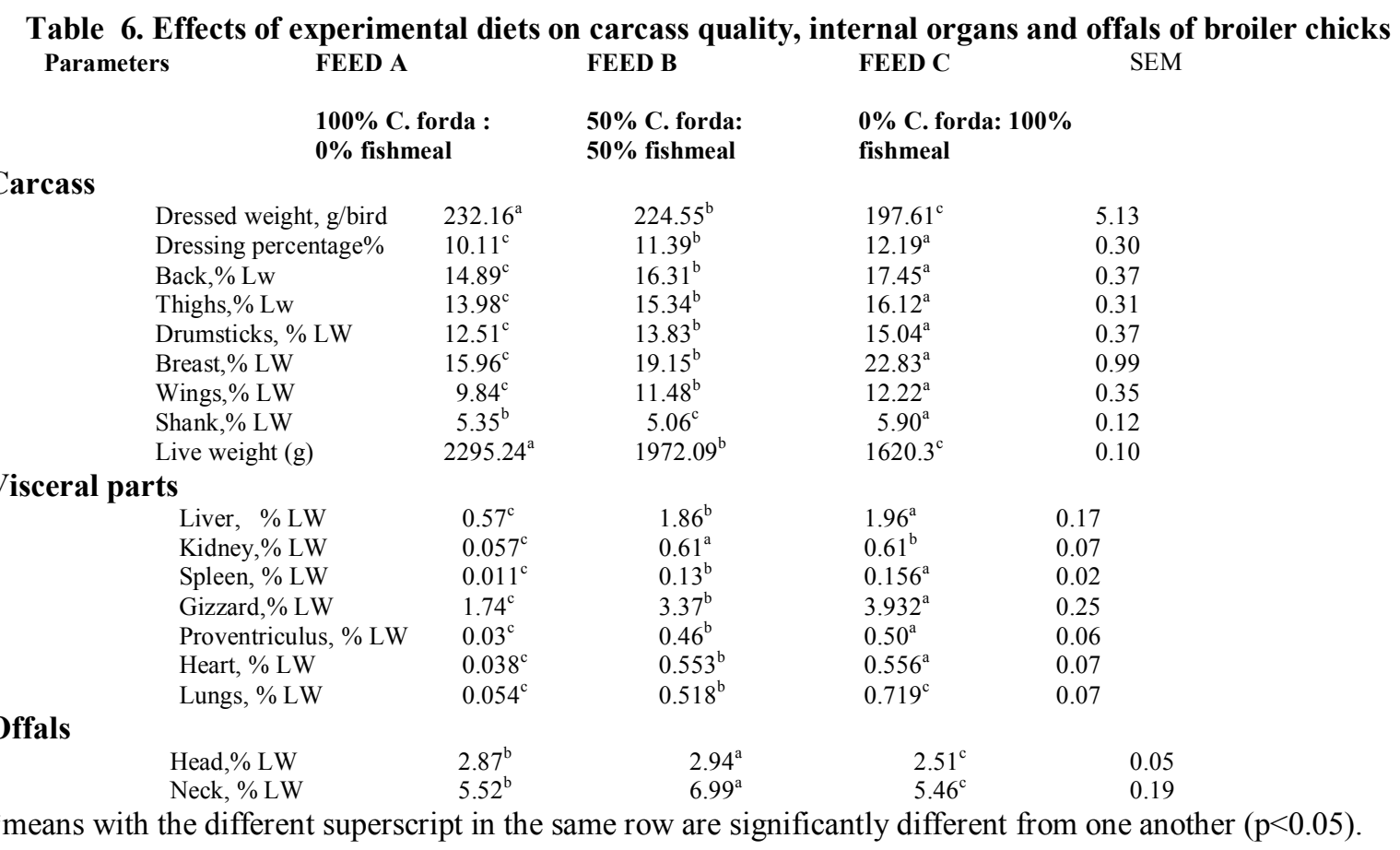

\section{Results And Discussion}

The nutritional compositions of the experimental diets compounded for the birds at the broiler and finisher stages are presented in Tables 1and 2 respectively. The diets were compounded to provide $20-23 \%$ Crude protein for the starter phase and $17-19.5 \%$ Crude protein for the finisher phase (Pfizer Nutrient Master Plan, 1992). Likewise, the diets were compounded to contain energy levels of 2,600 kcal and 2,800 kcal for the starter and finisher phases respectively (Moreson Feed Formulation Guide, 1998). From the two tables, it is evident that the energy levels of the broiler starter and broiler finisher diets used in the present study conform to compound standard diets for the starter and finisher stages.

The proximate composition of the Fish meal and Cirina forda meal is shown in Table 3. The crude protein content of C. forda (29.64\%) was lower than that of the fishmeal $(62.76 \%)$, the insect larva recorded superior values in crude fibre and dry matter contents. The crude protein at both starter and finisher stages met specified nutritional requirements ( PNMP, 1992). However, the proximate composition of C. forda larva was similar to those derived in other studies (Banjo et al., 2006). The lower values of the components obtained in some cases might not be unconnected with the long period of purchase of the larva after its natural period of occurrence in the field.

The effects of the formulated diets on growth parameters are presented in Tables 4 and 5. During the starter phase (Table 4), only the birds fed with the control diet had significantly lower body weight as compared to birds fed with $100 \%$ and $50 \% \mathrm{C}$. forda larva respectively $(\mathrm{p}<0.05)$.

The performance of broiler chicks at the finisher stage in terms of daily feed intake, mean weight gain and final body weight is shown in Table 5. The performance of the birds in terms of mean body weight and the final weight were significantly higher $(\mathrm{p}<0.05)$ in the feeds containing $\mathrm{C}$. forda larva than those of the control ( Feed C). However, the final weight of the birds were similar for the birds fed with feeds containing $100 \%$ and $70 \%$ C. forda larva, thus probably indicating more efficient utilization of the insect larva at lower level of inclusion.

The carcass, offals and organ characteristics of the birds are shown in Table 6. From the table, it is evident that treatment effect in all the carcass characteristics measured were significant $(p<0.05)$. In all the parameters determined as carcass parameters, significant difference $(p<0.05)$ was found. More specifically, it was observed that, the dressing weight percentage and live-weights of birds fed with the three feeds showed significant difference $(\mathrm{p}<0.05)$; in all the feeds used for the birds, those fed with $\mathrm{C}$. forda larva showed greater values than corresponding values obtained in the control feed. It can be inferred that, the meat yield from birds raised on this larva diets yielded higher edible meat than those fed with the control feed (Feed C). The results conformed to the rule that for any profitable broiler feeding strategy, one of the major objectives is maximization of final body weight (De Silva and Kalubowila, 2012).

The relative weights of seven visceral organs of broilers raised on Feed $\mathrm{C}$ were in all cases significantly higher $(\mathrm{P}<0.05)$ than the values obtained for Feeds A and B (containing $100 \%$ and $70 \% \mathrm{C}$. forda larva). The decrease in relative weights of the visceral organs was least in Feed A. It was observed that relative weights of 
the seven visceral organs of broilers decreasing with increase content of C. forda larva. A similar trend to this was also observed in the performance characters of the broilers at both starter and finisher stages of the birds. This observation agrees with the general observation that higher protein inclusion level in poultry diets depresses growth (Ash and Petaia, 1992; Opara, 1996). Consequently, this investigation has revealed that, not only are feeds compounded from $\mathrm{C}$. forda larva acceptable and utilizable by broiler birds, lower inclusion levels of the insect larva could be used at to obtain comparable level of performance as in conventional feeds.

\section{References}

[1]. Ande, A. T. (1991). Some aspects of the biology of Cirina forda (Lepidoptera: saturniidae) Ph. D Thesis Department of Biological Sciences, University of Ilorin, Nigeria.

[2]. AOAC. (1995). Official Methods of Analysis. $16^{\text {th }}$ Edn., Association of Official Analytical Chemists, Washington, DC, USA

[3]. Akintola A.J. and Oyegoke, O.O. (2002). Feeding trials of Cirina forda_(Lepidoptera: Saturniidae ) larvae on the fingerlings of Clarias gariepinus (Geoffrey). World. J. Biotech. 3 (2): 487-491.

[4]. Ash, A.J and Petaia, L.A (1992). Nutritional value of Sesbania grandiflora leaves for runminants and monogastric. Trop. Agri. 69: 223-207.

[5]. Banjo, A.D., Lawal, O.A and Songonuga, E.A(2006).The nutritional value of fourteen species of edible insects in Southwestern Nigerian. Afri. Jour. of Biotech 5(3). pp. 298-301

[6]. De Silva, P.H.G.J and Kalubowila, A.(2012). Influence of feed withdrawal for three hours time period on rowth performance and carcass parameters of later stage male broiler chickens. I. J. Appl. Sci. 2(2): 191-197

[7]. Dufour, D.I. (1987). Insect as food. A case study from the Northwest Amazon. Am. Anthropol. 89, 383-397.

[8]. Ene, J.C. (1963). Insects and man in West Africa. Ibadan University Press; PP 16-26.

[9]. Esonu, B.O, Emenalom, O.O, Udedibie, U, Herbert, C. F, Ekpor, Okoli, I. C and Iheukwumere, F.C (2001). Performanc and blood chemistry of weaner pigs fed raw Mucuna (Velvet bean) meal. Trop. Prod. Invest., 4:49-54.

[10]. Fasoranti, J.O. and Ajiboye D.O. (1993). Some edible insects of Kwara State. Entol.Soc. Amer. 139 (11)- 116

[11]. Gardner, J.C.M.(1957). Notes on larvae of the Saturniidae (Order Lepidoptera). East Africa Agric Jour. $22(1): 220-223$.

[12]. Golding, F.D.(1929) Preliminary notes on pest of the Shea-butter tree in Northern Nigeria. A. Bull of Agric. Nig 101-103.

[13]. Idufueku, A. (1984). Self-sufficiency in animal protein supply under changing economic fortunes. Nig. J. Animl. Prod. 11:14-21.

[14]. Kodondi,K.K, Leclercq, M, and Gaudin-Harding, F. (1987). Vitamin estimations of three edible species of Attacidae caterpillars from Zaire. Inter. J. Vitamin. Nutr. Res. 57:333-334.

[15]. Leng, R. A (2002). Future direction of animal protein production in a fossil fuel hungry world. Livestock Research for Rural Development.14 (15): 1-4.

[16]. Madubuike, F. N 1992. Bridging the animal protein gap for rural development in Nigeria. The potential of pigs. J. Agri. Rural Develop., 5:5-12.

[17]. Meyer- Rochow, V.B. (1975). Can insects help to ease the problem of world foodshortage? Commend. Search 6 (7), $26-262$.

[18]. Moreson, Nigeria Ltd.(1998). Feed formulation Guide, Moreson Nig. Ltd, Ikeja, Lagos, Nig. p.2.

[19]. Nworgu, F.C.(2004). University of forage meal supplements in broiler production.

[20]. Ph.D Thesis. Animal Science Dept. University of Ibadan, Nigeria: 136-160.

[21]. Opara, C.C. 1996. Studies on the use of Akichoria cordifolia leaf meal as feed ingredient in poultry diets. M.Sc Thesis, Federal University of Technology, Owerri, Nigeria.

[22]. Oyegoke, O.O., Akintola, A.J. and Fasoranti, J.O. (2006),. Dietary potentials of theedible larvae of C. forda (Westwood) as a poultry feed. Afri Jour. Bio Vol. 5 (19), PP. 1799-1802.

[23]. Pfizer (1992). The Nutrient Master Plan. Livestock feeds limited, Ikeja, Aba, Benin, Kaduna, Nigeria P. 2.

[24]. Steel, R.G.O. and Torrie, J.H. (1990). Principles and procedures of statistics withspecial reference to the Biological Science M.C. Gram Hill Book company Inc. New York.

[25]. Udedibie,A.B.I.,1997. Detoxifying Canavalia seeds. Netherlands CTA Spore No.72 Dec.,1997, p.9. 